\title{
WHY LAWYERS AND LEGAL EDUCATORS SHOULD CARE ABOUT (EPISTEMIC)
}

\section{JUSTICE}

Melanie Walker, Higher Education \& Human Development Research Group, University of the Free State, South Africa ${ }^{1}$

\section{INTRODUCTION}

Society shapes the law and the law, we hope, might shape society for the better in turn. Legal traditions and practices therefore surely ought to secure for all citizens the prerequisites of a life worthy of human dignity. In a speech to the Routledge-Modise Law School in Johannesburg in September 2008, Justice Kate O'Regan² drew on Antony Kronman's theory that one of the main characteristics identifying the practice of Law is that it is directly concerned with the public good. Lawyers have a responsibility to foster the legal system and the rule of law; at times, this might require them to suggest new laws or legislation; at other times, it might require them to criticize judgments which may not

\footnotetext{
${ }^{1}$ Melanie Walker is a Professor at the University of the Free State, South Africa. (walkermj@ufs.ac.za)

2 O'Regan, K. 'Lawyering in Our New Constitutional Order.' (2009). UCT News Alumni Magazine cited in Walker. M. Higher Education Pedagogies. (2016) Maidenhead: Open University Press \& SRHE
} 
appear correct; at other times, they may need to protect the rule of law itself.

Yet many in the profession - who are working for social justice - perceive there to be a lack of such an orientation in lawyers in current times. The former chairperson of the South African Human Rights Commission has thus said that "there is a growing perception that in spite of South Africa's having one of the best Constitutions in the world; its legal practitioners are losing their social consciences" 3 reminds us, lawyers should have a public calling and obligation for public service to foster the legal system on behalf of the marginalized, strengthening constitutional democracy and also changing individual lives. This role in strengthening democracy seems of some importance, given that it appears that democracy is fragile nearly everywhere. Delivering the Nelson Mandela annual lecture in Johannesburg in July 20184, Barack Obama relayed his concerns regarding the subversion of free media, the use of social media as a vehicle for hatred and propaganda, as well as how some politicians openly lie and discard facts for their own needs. His lecture sought to defend democracy and civil rights as "the better story to tell" and to resist the potential "undoing" 5 of democracy in current times.

This leads me to ask how legal education might contribute to addressing this urgent

\footnotetext{
${ }^{3}$ Cited in Sarkin, J. 'Promoting Access to Justice in South Africa: Should the Legal Profession have a Voluntary or Mandatory Role in Providing Legal Services to the Poor?' (2002). South African Journal on Human Rights, 18 (4), 630-644

${ }^{4}$ Marrian, N. and Quintal, G. 'Obama: resist politics of fear and resentment.' (2018). Business Day, 18 July:1 ${ }^{5}$ Ibid, (n.4)
} 
challenge. Here is my claim that follows: epistemic justice and injustice are deeply relevant to a just legal system, its practitioners, to clinical practice learning, and hence to legal educators in universities like yourselves. I acknowledge, nonetheless, that universities and clinical practice settings may act in contradictory ways, with the potential to empower, co-existing with the potential to oppress and marginalize. We need to work for more of the first and less of the second for justice in a non-ideal world ${ }^{6}$.

Epistemic injustice, on which I elaborate later, refers to those forms of unfair treatment that relate to issue of knowledge, understanding and participation in communicative practices. Put simply, if you are in a disadvantaged position to influence discourse you are subject to epistemic injustice and reduced epistemic agency ${ }^{7}$. That is, you are wronged specifically in your capacity as a knower; you do not have a voice that is recognized, and you are placed at an epistemic disadvantage.

I hope thus to make a persuasive case for adding an epistemic justice-facing capability to the eight multi-dimensional, intersecting public-good professional capabilities identified by Monica McLean and myself ${ }^{8}$. We arrived at these both theoretically and empirically

\footnotetext{
${ }^{6}$ Sen, A. The Idea of Justice. (2009) London: Allen Lane

${ }^{7}$ Kidd. I., Medina, J, and Pohlhaus, G. Jr. 'Introduction' (2017); in Kidd. I., Medina, J, and Pohlhaus, G. Jr (Eds.). The Routledge Handbook of Epistemic Injustice. (2017) London \& New York: Routledge ${ }^{8}$ Walker, M., \& McLean, M. Professional education, capabilities and contributions to the public good. (2013). London: Routledge.
} 
using five professional education case studies, including law, at three South African universities. The details of the method and the cases can be found in the book ${ }^{9}$.

\section{CAPABILITIES}

First, a brief outline of what I mean by 'capabilities'.

The capability approach ${ }^{10}$ is a broad normative framework rooted in a philosophical tradition that values individual freedoms, and is used for the evaluation and assessment of individual wellbeing, social arrangements and the design of policies and proposals about social change. The approach conceptualises "good" development as freedom constituted by "human capabilities", rather than only as national income or people's subjective preferences. Income does not tell us who has the money or what it is used for, while preferences may be subject to adaptations in the light of poor living, such that one comes to accommodate limited opportunities and reduce aspirations for the future. The core focus of the approach is on the effective opportunities people have to be and to do what they have reason to value. It highlights substantive freedoms ('capabilities'), and

\footnotetext{
9 See Walker, M., \& McLean, M. Professional education, capabilities and contributions to the public good. (2013). London: Routledge.

${ }^{10}$ See Sen, A. Development as Freedom. (1999). Oxford: Oxford University Press. and Sen, A. The Idea of Justice. (2009). London: Allen Lane. See also Nussbaum, M. Women and Human Development. (2000). Cambridge: Cambridge University Press
} 
outcomes or what is actually achieved ('functionings'). Professional 'beings and doings' that are valuable to the professionals who emerge from higher education would be 'functionings'; such 'functionings' would be proxies for 'professional capabilities'. Importantly, with capability also comes responsibility for what we do, and the obligations we owe to others ${ }^{11}$. The capability approach further takes into account intersecting 'conversion factors', that is the personal, social and environmental factors that shape our ability to transform our means to achieve into capabilities and functionings. This includes, in my view, structures of inequality such as race, class, gender, and so on. Finally, agency is significant for Sen; we are not passive spectators in our own development but active agents who makes choices, albeit under specific contextual circumstances ${ }^{12}$.

${ }^{11 S e n}$, A. The Idea of Justice. (2009). London: Allen Lane.

12 Ibid (n.11) 


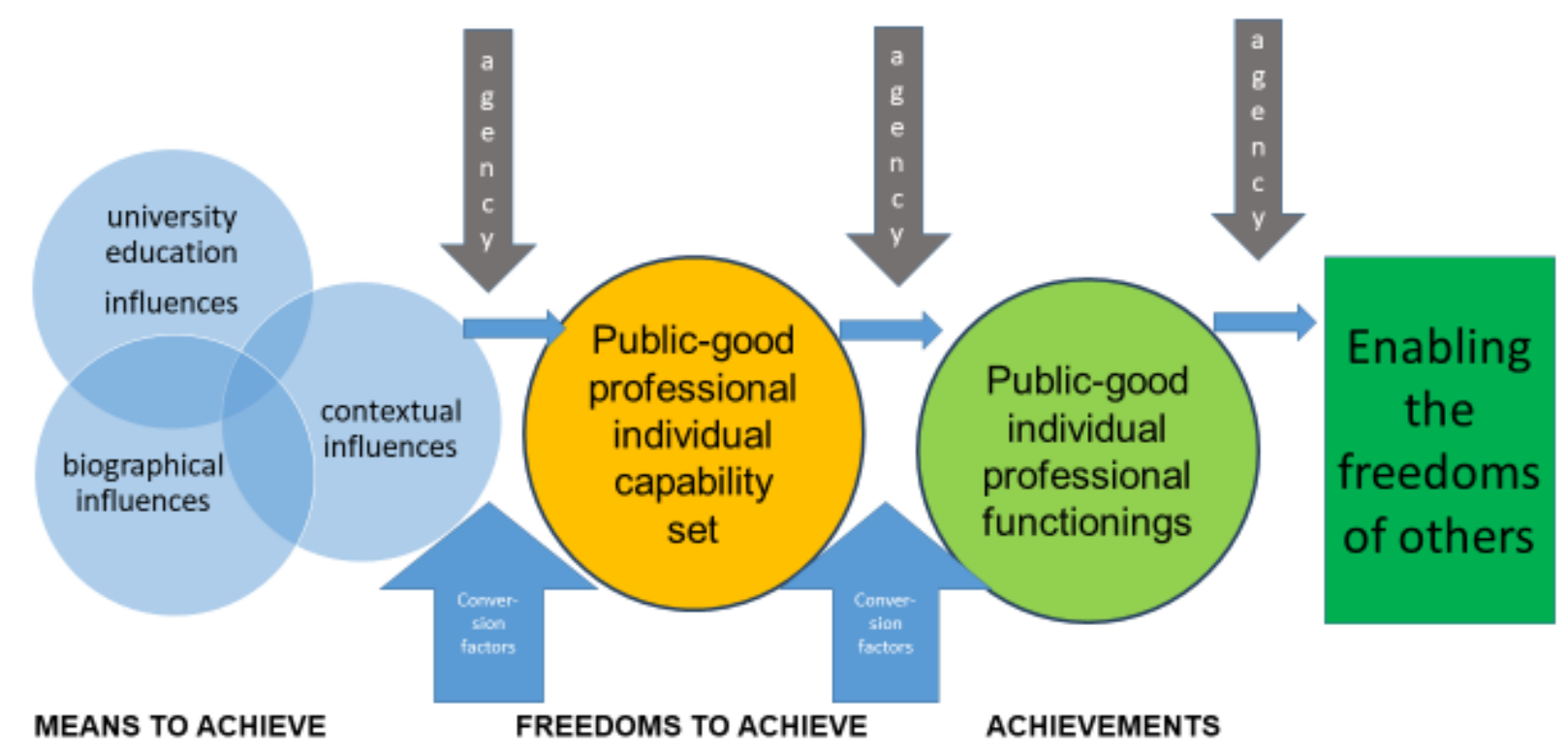

The approach can be used as a normative framework to tell us what information we should look at - do people have valuable capabilities and who has them - if we are to judge how well someone's life is going. More broadly it can be used as an evaluative framework to conceptualise, measure and evaluate human wellbeing ${ }^{13}$. What matters in arriving at these assessments, for Sen ${ }^{14}$ is the lives that people can actually live - what they are able to do and to be (such as having access to legal services and being treated fairly).

\footnotetext{
${ }^{13}$ Crocker, D. A., \& Robeyns, I. 'Capability and Agency', (2010), in Morris, C. W. Ethics and economics. (2010). Amartya Sen, 40-59.

${ }^{14}$ Sen, A. The Idea of Justice. (2009). London: Allen Lane.
} 
It also provides a framework for an examination and understanding of the purposes of universities and hence of legal education settings, including the clinical, because it encourages us to consider individual opportunities for wellbeing achievement and agency in and through higher education. Through a capabilities lens, higher education is not solely a means for individuals to achieve economic gains through acquiring knowledge and skills for employment. Instead, the approach asks us how higher education is contributing to human development ${ }^{15}$, by recognising an expansion of the capabilities and functionings that people have reason to value. Thus, various higher education studies have explored the approach's theoretical richness in conceptualizing and articulating the changes that need to take place in universities if they are to contribute to human development and social justice ${ }^{16}$.

To recap the existing eight public-good professional capabilities on mine and Monica's list (see table 1), these were: informed vision; knowledge and skills; affiliation; resilience; social and collective struggle; emotional reflexivity; integrity; and, confidence and

\footnotetext{
${ }^{15}$ Haq, ul M. 'The human development paradigm' (2003), in S. Fukuda-Parr and A.V. Kumar (Eds) Readings in Human Development. Oxford: Oxford University Press, 17-34 ${ }^{16}$ See for example Walker. M. Higher Education Pedagogies. (2006). Maidenhead: Open University Press \& SRHE and Boni, S. And Walker, M. Higher Education and Global Human Development. (2016). London and New York: Routledge. among others.
} 
assurance ${ }^{17}$. All the capabilities are important and any trade-offs would need careful and wide deliberation.

Table 1: Public-good professional capabilities extrapolated from empirical functionings, Walker and McLean, 2013

\section{Examples of Functionings}

Professional capability

Understanding how the profession is 1. Informed vision

shaped by historical and current socio-

economic, political context nationally and

globally; understanding how structures

shape individual lives; being able to

imagine alternative futures.

Care and respect for diverse people; 2. Affiliation (solidarity)

communicating professional knowledge

in an accessible way/courtesy and

patience.

Perseverance in difficult circumstances. 3 . Resilience

Promoting human rights; identifying 4. Social and collective struggle

17 Walker, M., \& McLean, M. Professional education, capabilities and contributions to the public good. (2013). London: Routledge. 
spaces for social change to reduce

injustice.

Empathy/narrative imagination; 5. Emotions (emotional reflexivity after

compassion. July 2012)

Acting ethically. $\quad$ 6. Integrity

Having confidence in the worthwhileness 7. Assurance and confidence

of one's professional work; having

confidence to act for change.

Having a firm, critical grounding in 8.Knowledge and skills

disciplinary, academic knowledge; being

enquiring, critical, evaluative,

imaginative, creative and flexible.

In our South Africa law case study, functionings included: being self-aware and reflexive; being conscious of what a person wants to achieve as a professional and one's values; and, being able to decide which career direction to move in. Students identified that it is important to have a sense of self-belief and self-confidence in yourself as a lawyer. Most felt it important that each individual is able to choose their career path autonomously. For many, being a lawyer in itself was inherently tied up with acting in the public good. 
Rohan, a lecturer, saw law as a profession that intrinsically involves acting in the interest of others, who lack the legal skills to defend their own interests. In other words, he said, "there is value in the training of the attorney in that it's a profession in the interest of other persons"18.

Our eight professional capabilities are open to debate and to changes, and we welcome this. Moreover, we did not claim that these capabilities are universal. They were developed in the specific context of transformation seeking but highly unequal postapartheid South Africa so that the list was understood to be the capabilities that would equip future professionals to act for the public good. However, we did argue that a normative capability set, such as the one proposed, can reveal injustices and also possibilities for working towards non-ideal justice in practice settings, and this argument would be widely relevant.

Can we, should we, then make space for a distinctively epistemic capability - beyond knowledge and skills - on the list?

${ }^{18}$ Walker, M., McLean, M., Dison, A. and Vaughan, R. 'Higher Education and Poverty Reduction: The Formation of Public Good' (2010)., Unpublished paper. School of Education: University of Notthingham. pp.138 


\section{WHY EPISTEMIC JUSTICE MATTERS FOR JUSTICE}

Here is my argument for epistemic justice and a corresponding capability. In making my case, bear in mind that I take for granted that what is required for fairness is a foundation of proficiency in technical legal reasoning, knowledge of law, and the constraints of procedure - they play a central role in working with clients and supply the bounds within which epistemic justice must work.

My claim is that legal educators, lawyers and other legal professionals should care about epistemic justice and care about doing epistemic justice in their own practice actions across all branches of the law, whether the injustices generate micro or macro exclusions. Access to equality and fairness before the law for all, and, understanding the law in more mundane and more dramatic contexts matters in a just society. Legal educators including but not confined to clinical legal educators - train and educate future legal practitioners so what they do matters too for a just society and for a legal system which is oriented to the public good of all and not just the few. How then might our own epistemic conduct be more just in the face of the discrimination arising when unfair biases cause people to underestimate the credibility of certain individuals and groups, often socially disadvantaged groups or those different from ourselves. Such prejudices can occur in a great diversity of communicative exchanges and can negatively impact on decision-making in legal contexts. 


\section{FRICKER'S ‘FAILURE FIRST’ METHOD}

Specific attention to epistemic injustice can alert us to justice gaps and blind spots; it is what philosopher Miranda Fricker ${ }^{19}$ calls a methodological approach of 'failure first' 20 . She explains that it is often revealing to start with the negative, to begin with a picture of how things will tend, under the relevant socio-historical circumstances, to go wrong. Epistemic justice is then best conceived as always sustained under tension, she says. Of course, these tensions will differ from society to society and we should each consider the claims and argument in relation to the specificity of our own contexts.

The context for my first illustrative example is apartheid South Africa in May 1976 just six weeks before the history-changing Soweto student resistance erupted. The occasion is the lengthy Supreme Court trial of nine student leaders from the Black People's Convention (BPC) and the South African Students' Organization (SASO). The banning orders of charismatic black consciousness activist, Steve Biko, were relaxed so that he could testify on their behalf. ${ }^{21}$ In the example, Biko is giving evidence before white,

\footnotetext{
${ }^{19}$ Fricker, M. ‘Epistemic Contribution as a Central Human Capability'. (2015). In G. Hull (Ed.) The Equal Society. Cape Town: UCT Press, 73-90

${ }^{20}$ Ibid, 2015, pp.3

${ }^{21}$ The nine were found guilty under the Terrorism Act and sentenced to periods of imprisonment on Robben Island. Eighteen months later Biko himself would die of injuries sustained during interrogation. His death stunned and shocked the world. But not Jimmy Kruger, the then Minister of all things - Justice, who stated that Biko's death "left him cold".
} 
Afrikaner Judge Boshoff, a man clearly skeptical of the epistemic capabilities of Africans and their ability to understand democracy or the concept of one person one vote. There is epistemic injustice at work here in the judge's prejudiced refusal to accept black Africans as credible knowers. After an exchange as to whether or not there are any examples of one man [sic] one vote in any African country, Boshoff asserts (and the irony would not be lost on anyone with some knowledge of apartheid): "Yes but democracy is really only a success if the people who have the right to vote can intelligently and honestly apply a vote... I mean surely you must know who you are voting for, what you are voting about. Assuming that they vote on foreign investment, what does a peasant know about foreign investment?". And later, "if we have to debate whether this government should go on the gold standard or go off the gold standard will you feel you know enough about it to be able to cast an intelligent vote about that... such that the government should be based on that vote?"22. For the judge, black South Africans simply cannot be credible as knowers or tellers about democracy locked as he is into a decades long belief that blacks were inferior, "unable to formulate their thoughts without white guidance" as Biko ${ }^{23}$ wrote. This is a vivid example of failing to accept someone's testimony because of racial prejudice, and hence a failure to recognize black South Africans as capable of transmitting

22 Biko, S. I Write What I Like. (1978). Northlands: Picador Press, pp.145

${ }^{23}$ Ibid, (1978)., pp.98 
knowledge about their own situation and coming to their own judgements about a different way of doing things.

Here is a further example of epistemic failure. Some of you may recall the murder of black teenager Stephen Lawrence in London ${ }^{24}$, one night in 1993, while waiting with his friend Duwayne Brooks for a bus to get home. Brooks saw a group of five or six white youths on the opposite side of the street, moving towards them. Brooks claimed that he heard one of Lawrence's assailants saying, "what, what, nigger?" as they all quickly crossed the road and "engulfed" Lawrence. As the attackers forced Lawrence down and stabbed him, Brooks began running, and shouted for his friend to run with him. They both ran, but Lawrence collapsed and bled to death after 130 yards. For a whole generation, Brooks said, the effect of the case was seismic, a moment when many lost trust in the police, the judiciary and politicians. In the wake of the murder, the police embarked on a campaign of harassment - not of the alleged perpetrators- but astonishingly of Brooks. The campaign would go on for years. At first they tried to discredit his evidence, then attempted to ruin him personally. There were regular arrests, the charges either quietly dropped or defeated. The point here is that Duwayne Brooks - who was there - was discounted as a credible witness simply because he was young, male and black. He was

\footnotetext{
${ }^{24}$ Bowling, B. 'Stephen Lawrence: his death changed British law forever but trust in police has yet to recover.' (2018). Available at https://theconversation.com/stephen-lawrence-his-death-changed-britishlaw-forever-but-trust-in-police-has-yet-to-recover-95091
} 
wronged and undermined specifically in his capacity and credibility as a knower because of prejudice on the part of the police and others. Systemic and individual racial prejudice triumphed over the evidence of Duwayne Brooks and over justice for Stephen Lawrence because of these epistemic wrongs.

Here is one final example. In Rochdale, England in the $2000 \mathrm{~s}^{25}$, police launched an investigation into the town's sex gangs. Yet, despite powerful evidence against them, their child victims were written off as 'unreliable witnesses' who, according to the Crown Prosecution Service, had made 'lifestyle choices' to become 'prostitutes'. The police hadn't interviewed Amber one of the victims. Instead, they had arrested her - on suspicion of procuring a child into prostitution. Her crime? Accompanying a friend who was four months younger to the kebab shop where some of the abusers hung out. Yet at 15, she was an under-age victim herself, meanwhile, her sister, Ruby, had been raped by a married Asian man at the age of 12 , and subsequently had an abortion. Or the senior officer who said to Maggie Oliver ${ }^{26}{ }_{L}$ "Maggie, let's be honest about this. What are these kids ever going to contribute to society?" he said. "In my opinion, they should have just been drowned at birth."

\footnotetext{
${ }^{25}$ See Oliver, M. One Brave Detective's Battle To Expose The Rochdale Child Abuse Scandal. (2019). London: John Blake. for powerful account of the case.

${ }^{26} \mathrm{Ibid},(2019)$.
} 
These are all dramatic examples, but they are also real, not made up scenarios. They serve to alert us to the potential and actual consequences of epistemic failures in societies. Readers could no doubt think of many more examples of the law at work, which are more or less epistemically fair and just, more or less every day.

\section{MIRANDA FRICKER'S “EPISTEMIC CONTRIBUTION CAPABILITY” AND THE FUNCTIONING OF BECOMING AND BEING AN EPISTEMIC CONTRIBUTOR}

Fricker $^{27}$ argues that the capability for epistemic contribution - and I would add the functioning of being an epistemic contributor, too - should be a central capability on any list. It is fundamental to human flourishing to have the opportunity and freedom to give and receive information and understanding, to be a credible knower and teller in society, and to participate in society's meaning-making, an opportunity denied to Steve Biko, Duwayne Brooks and Tom Robinson. Two forms of epistemic materials contribute: informational (including evidence, doubt, hypothesis, and argumentation), and interpretational (making sense, alternative ways of seeing). To this end, Fricker outlines two forms of epistemic injustice: testimonial (not listened to because of who you are) and

\footnotetext{
${ }^{27}$ Fricker, M. ‘Epistemic Contribution as a Central Human Capability'. (2015). In G. Hull (Ed.) The Equal Society. Cape Town: UCT Press, 73-90
} 
hermeneutical (not having the means to communicate intelligibly to others about something and hence not being an equal participant in the generation of shared meaning).

Hermeneutical injustice is structural (as in the Lawrence case which later revealed structural racism in the police force). It is evident in attempts to contribute and participate in social meaning-making and hence in attempts to make an experience intelligible to oneself or to someone else, for example, experiences of racism or sexual harassment before there was a social understanding to understand this form of harassment and other social exclusions. Another example might be that of post-traumatic stress disorder experienced by soldiers (and others). Before we had a name for this, persons suffering this form of trauma were labelled as cowards, or depressed, or even malingering - there was no name to communicate or acknowledge their suffering.

Hermeneutical injustice also arises when the injustice is understood by the powerless (such as among black South Africans under apartheid) but is still not communicable to those with power because they will not or cannot hear because the person speaking may be a single mother on benefits, a migrant, working class, and so on. Experiences that are outside of what is marked out as the norm are not heard or acknowledged, and hence not cared about. This unequal participation in generating social meanings generates structural hermeneutic marginalization of a person or group in the absence of nondistorted discursive resources among the dominant. There are compelling examples of 
thus under apartheid in Miriam Tlali's 1968 novel (republished in 2004), Between Two Worlds $^{28}$, based on her own experiences. For example, she reveals the epistemic obtuseness of her white colleagues with regard to the accepted narrative of South African society. Thus, one remarks that, "the critics overseas are ill-informed about the true situation. They only receive false information. South Africa is a most peaceful country. People are free to go where they like, and say what they feel" ${ }^{29}$. For Mrs Stein - and others like her there is a closed hermeneutic loop.

In both cases of hermeneutic injustice people are denied epistemic functionings; they cannot be epistemic contributors.

The second form, testimonial injustice ${ }^{30}$, arises through a deficit of credibility owing to prejudice in the hearer's judgment about the speaker (Duwayne Brooks was not believed because of who he was). Philosopher Michael Sullivan ${ }^{31}$ explains that in the case of criminal law, opportunities for epistemic injustice abound because practices in the legal system are unable to understand the experiences of others in difficult situations of which the legal practitioners may have no knowledge. We may also find disparities in

\footnotetext{
28 Tlali, M. Between two worlds. (2004). Broadview Press.

${ }^{29}$ Tlali, M. Between two worlds. (2004). Broadview Press., pp.207

${ }^{30}$ Fricker, M. Epistemic Injustice. Power and the Ethics of Knowing. (2007). Oxford; Oxford University Press

${ }^{31}$ Sullivan, M. 'Epistemic Justice and the Law' (2017). in Kidd. I., Medina, J, and Pohlhaus, G. Jr (Eds.). The Routledge Handbook of Epistemic Injustice. (2017) London \& New York: Routledge
} 
sentencing for similar offences and these, he says, are not unrelated to social power and epistemic authority. These are real practical effects and consequences.

It may also take pre-emptive form, when, for example a lecturer does not call on a student to respond, to enter the debate and so on because they are assumed - even before they can speak - not to be credible about the subject under discussion. Hookway describes this as "the participant perspective" 32 where someone is not recognized as competent to participate in activities whose content is intrinsically epistemic - they are not invited to contribute, or their contributions may be disregarded in furthering the discussion. He points out that if we come to lack confidence in our ability to contribute, this eventually attacks "also our ability to properly participate in epistemic activities at all"33. In higher education, students from working class or migrant backgrounds may lack confidence and may be made to feel inadequate. In this case students would be both non-knowers and non-participants and subject to pedagogic injustices as a secondary effect. A further example might be in court where a judge overrules all attempts by a defence lawyer who attempts to portray his client to the jury on the basis that for the judge the client is simply not credible and his or her story may be simply not allowed to be heard. Jose Medina thus

\footnotetext{
${ }^{32}$ Hookway, C. 'Some Varieties of Epistemic Injustice: Reflections on Fricker'. (2010). Episteme: A Journal of Social Epistemology, 7 (2):151-163

${ }^{33} \mathrm{Ibid}, 2010$
} 
stresses that epistemic injustice is interactive and performative, it is made in communicative spaces $^{34}$.

In both hermeneutical and testimonial injustice, the primary exclusion is being wronged as a knower. But - as noted - this gives rise to secondary wrongs in practice, for example not being believed by a judge, jury or a magistrate or ignored in a university classroom. Both hermeneutical and testimonial forms also work together in practice. As Medina explains, "testimonial insensitivities and hermeneutical insensitivities converge and feed each other" 35 . Both forms are also iterative so that repetitions secure the injustices. If a person is repeatedly not taken seriously as a knower, they lose confidence in their own ability. The capability for epistemic contribution is frustrated by not appreciating or mistrusting people as knowers and is indicative of wider structures of inequality. Localized prejudices and injustices may be utterly disastrous for the subject, especially if they are repeated frequently so that the injustice is persistent. As she further explains being wronged in one's capacity as a giver of knowledge "can cut deep" 36.

The strength and reach of Fricker's approach is the way she identifies intrinsically

\footnotetext{
${ }^{34}$ Medina, J. 'Varieties of Hermeneutical Injustice 1' (2017). in Kidd. I., Medina, J, and Pohlhaus, G. Jr (Eds.). The Routledge Handbook of Epistemic Injustice. (2017). London \& New York: Routledge ${ }^{35}$ Medina, J. ‘Hermeneutical Injustice and Polyphonic Contextualism: Social Silences and Shared Hermeneutical Responsibilities.' (2012). Social Epistemology, 26 (2), 201-220, pp.206

${ }^{36}$ Medina, J. 'Varieties of Hermeneutical Injustice 1' (2017). in Kidd. I., Medina, J, and Pohlhaus, G. Jr (Eds.). The Routledge Handbook of Epistemic Injustice. (2017). London \& New York: Routledge
} 
epistemic forms of injustice - wrongs done to someone as a knower; yet egalitarian epistemic contributions are fundamental to human well-being and, she argues, to political freedoms. Fricker explains that in any cultural context, the question of who gets to contribute epistemically to shared knowledge and/or shared social understandings in any given practical context, is a matter of epistemic equality or inequality. It is also fundamentally relational in its process, practices and effects. We flourish (not or) as epistemic contributors in relationships with and through others. In oppressive contexts (racism, sexism, classism etc.) the powerful undermine others with less power in their epistemic capacity, undermining them in their humanness and dignity. It is humiliating and demeaning and reduces confidence and, Fricker says, the development of intellectual courage. We end up not being at all sure of what we think ourselves and our personhood is diminished.

To be sure, those who hold political and social power, whether in the broader society or in higher education institutions (or both), also wield epistemic power. Anticipating many of the current debates on epistemic justice, in 1978 Biko wrote, "that the most potent weapon in the hands of the oppressor is the mind of the oppressed" ${ }^{37}$. Even earlier, in 1767 French lawyer, Joseph Servan, explained that, "when you have thus formed the chain of ideas in the heads of your citizens, you will then be able to pride yourselves on

${ }^{37}$ Biko, S. I Write What I Like. (1978). Northlands: Picador Press, pp.49 
guiding them and being their masters.... [on] the habitual union of ideas...on the soft fibres of the brain, is founded the unshakeable base of the soundest empires" ${ }^{\prime 38} \cdot{ }^{39}$

At stake is that our epistemic lives whether in higher education or elsewhere are not abstractions but active, practical and relational, done well or less well ${ }^{40}$. Fricker's epistemic contribution capability is fundamental for accessing critical knowledge and requires pedagogical and other conditions for critical reasoning and dialogue to achieve "the epistemically multi-perspectival context in which citizens may come to believe truths in the mode of knowledge" ${ }^{\prime 4}$. Ideas and knowledge matter for participation in inclusive meaning-making (and hence to politics, education, the professions, and so on) so that who has access to these epistemic goods at various layers of society is then a matter of justice.

\footnotetext{
38 Servan, J.M.A, Discours sur l'administration de la justice criminelle. (1767) cited in Foucault, M. Discipline and Punish. (1977). London: Penguin Books., pp.102-103

39 This includes the impact of colonization on knowledge and whose knowledge and knowledge contributions are regarded as credible. See, for example, De Sousa Santos's (2015) decoloniality argument for inclusive "ecology of knowledges", for global cognitive justice, and for a more expansive and generous ways of seeing, thinking and knowing in universities and elsewhere.

${ }^{40}$ Barker S.R., Crerar C. and Goetze, T. 'Harms and wrongs in epistemic practice.' (2018). In: Barker S.R., Crerar C. and Goetze T., (eds.) Harms and Wrongs in Epistemic Practice. (2018). Royal Institute of Philosophy Supplements, 84. Cambridge University Press, Cambridge, UK., pp. 1-21.

${ }^{41}$ Fricker, M. ‘Epistemic Contribution as a Central Human Capability'. (2015). In G. Hull (Ed.) The Equal Society. (2015). Cape Town: UCT Press, 73-90., pp.15
} 
Fricker ${ }^{42}$ asserts her basic claim that any epistemic injustice (including exclusions from access to and being understood in the context of the law and also in legal professional education) wrongs someone both as a giver of knowledge and as a credible informant so that a person is prevented from becoming fully who they are. Epistemic oppression would constitute a "persistent epistemic exclusion that hinders one's contribution to knowledge production, an unwarranted infringement on the epistemic agency of knowers $^{\prime 43}$. Her capability is quite simply, she argues, universally essential to human flourishing and hence an egalitarian value because one of our most basic human needs, is to use our reason, to sift and evaluate information, to make interpretations and sense of our shared lives. All persons should then be able to make epistemic contributions and to have such contributions taken up socially, neither rejected nor under-rated - whether we are black or white, rich or poor, migrant or citizen, man or women, able-bodied or differently-abled, young or old, and so on. Epistemic justice fosters the contestation of ideas in the public sphere, and this in turn requires struggling both for personal change and conditions and structures of epistemic justice. Importantly, epistemic justice can be contested so that epistemic failure is seldom complete, and structural possibility seldom entirely open. In short and to reiterate, 'thick' epistemic contributions are fundamental to human flourishing; this is important for everyone.

\footnotetext{
${ }^{42}$ Fricker, M. Epistemic Injustice. Power and the Ethics of Knowing. (2007). Oxford; Oxford University Press

${ }^{43}$ Dotson, K., 'Conceptualizing epistemic oppression'. (2014). Social Epistemology 28 (2): 115-138
} 


\section{THE CASE FOR ADDING A NEW PUBLIC-GOOD PROFESSIONAL CAPABILITY}

Wolff and De-Shalit's two law-oriented capabilities on their own list ${ }^{44}$, adapted from that of Martha Nussbaum, might be subsets of the epistemic contribution capability ${ }^{45}$. These are: 1) living in a law-abiding fashion - the possibility of being able to live within the law; not to be forced to break the law, cheat, or to deceive other people or institutions; and, 2) understanding the la - having a general comprehension of the law, its demands, and the opportunities it offers to individuals, not standing perplexed before the legal system or perplexed in front of a legal practitioner. As one of the legal NGO workers interviewed for our South Africa law case study explained: "having a general comprehension of the law, I think that's critical. That informs the relations that we have in society and our obligations and the state's obligations. It's the glue that keeps it together - and yet people don't understand the law. They don't understand their rights at an absolute basic level not understanding their rights it means they can't respect those rights and they can't access those rights" ${ }^{46}$. For access to the law, one of our case study students supported Wolff and De-Shalit in highlighting the importance of lawyers being able to relate to and properly communicate with their clients because the legal world can be very alien for

\footnotetext{
${ }^{44}$ Wolff, J., \& De-Shalit, A. Disadvantage. (2007). Oxford University Press on Demand.

${ }^{45}$ Nussbaum, M. Women and Human Development. (2000). Cambridge: Cambridge University Press

${ }^{46}$ Walker, M., McLean, M., Dison, A. and Vaughan, R. 'Higher Education and Poverty Reduction: The Formation of Public Good'. (2010). Unpublished paper. School of Education: University of Notthingham. pp.139
} 
people from different backgrounds ${ }^{47}$ : "my clients said that they go to court and then they don't understand what the magistrate is saying, so they come here to the legal aid clinic. When I see them, they're looking for someone to represent them and be able to speak the language, the law language. Even if they don't understand it, they trust us to know 'Ok, what you're saying is correct'. They're looking for someone to speak in a different language on their behalf'"'48.

In many ways, this mode of communication is related to seeing clients as human and respecting them. Thus another student stated: "What is important is that you don't indulge in this legal jargon with indigent clients, stick to the basic language and that's how you respect them as well...you don't make them feel that 'I'm superior and you're inferior', you speak to them, you maintain that professionalism but you try to communicate with them on an equal basis, so that they open up" ${ }^{\prime 4}$. A third remarked that, 'Each client should be treated with dignity, not making them feel inferior: "'you are a person, you are special, you have your dignity, hold onto that, you're not the person he [your husband] says you $\operatorname{are}^{\prime \prime \prime 50}$. It is then important to make the law accessible - not expecting people to understand legal terms and processes. As the then Dean of the Law Faculty commented,

\footnotetext{
47 Wolff, J., \& De-Shalit, A. (2007). Disadvantage. Oxford University Press on Demand.

${ }^{48}$ Walker, M., McLean, M., Dison, A. and Vaughan, R. 2010. Higher Education and Poverty Reduction: The Formation of Public Good, Unpublished paper. School of Education: University of Notthingham., pp.141 ${ }^{49}$ Ibid, (2010)., pp.141

${ }^{50}$ Ibid, (2010).
} 
“'You can't really do much with a lawyer who can understand the most arcane and complicated statute...but can't even translate that into plain English for a client'" ${ }^{\prime \prime 1}$.

In short, the legal system should not unfairly prejudice the vulnerable. As one lawyer told us, "'people in low-income areas [or it could be under conditions of a lack of democratic freedoms as in apartheid South Africa] do not have an understanding of their rights...I think we as a profession have a duty there ${ }^{\prime \prime \prime 52}$. Another lawyer working for an NGO felt that knowledge about your own society was possibly as significant as the knowledge of the law itself, "knowledge of not only the theory but also, and maybe more importantly, a knowledge of what's happening in society, and to be aware of what, and how the rules of society operate and how those rules can be used creatively to find solutions to society's problems ${ }^{\prime \prime 3}$. A third, who worked for a legal professional standards body, felt it was important for professionals to be aware of the effect they can have through their work, "I think professionals can play a role. I think lawyers, urban planners, engineers, and so on, when they do the kind of work they do, should have in mind the makeup of society and plan and engineer in accordance with that. So I firmly believe that professionals must always be aware of their role in society at all times" ${ }^{\prime 54}$. Finally, one of

\footnotetext{
${ }^{51} \mathrm{Ibid},(2010)$.

52 Walker, M., McLean, M., Dison, A. and Vaughan, R. 2010. Higher Education and Poverty Reduction: The Formation of Public Good, Unpublished paper. School of Education: University of Notthingham.,pp.139

${ }^{53}$ Ibid, (2010)., pp.139

54 Ibid, (2010)., pp.139
} 
the students remarked that professionals can enable people's access to justice, "for them to actually know that there is a way out...you don't have to sit in that same situation" 55 .

In other words, everyone ought to be enabled and respected as an epistemic contributor, and the law has a part to play in enabling this capability.

In arguing for adding a new public-good professional capability, there are two intersecting levels in play (see figure 1): 1) the level of general capabilities - that is our freedoms to be and do in ways we have reason to value for well-being in the general population and, arising from that, the specific capabilities that would enable legal practitioners professionally to foster law specific capabilities such as those of Wolff and De-Shalit ${ }^{56}$ and to advance epistemic justice. If some but not others are unable to access or understand the framework of human rights and legal rights - or even everyday legal processes governing the purchase and sale of property or rental agreements, or divorce law, or family law affecting the rights of children, or even corporate law - that obtain in a society, then we have reason to ask how fair the law or legal processes and outcomes are. 2) The second level is that of legal professionals who themselves needs access to the capability in order to value it, understand it, and foster it for others, and clinical legal education in particular can play a significant role in advancing this capability and

\footnotetext{
55 Ibid, (2010)., pp.139

56 Wolff, J., \& De-Shalit, A. Disadvantage. (2007). Oxford University Press (On Demand).
} 
fucntioning. The advance or constraint of the epistemic contribution capability - both generally and specifically for legal professionals - then offers a tool to identify injustices and think about how to move towards a fair and inclusive legal system and society.

I therefore argue for adding another professional capability - that of epistemic contribution - to be fostered in law students through an appropriate curriculum and pedagogical arrangements and - through legal practitioners enabled and made available to the public at large. It is a capability which seems especially important in clinical legal education in universities and in practicing law for the public good.

\section{EDUCATION AND DEVELOPING THE CAPABILITY}

Fricker's conceptualization requires educational work ${ }^{57}$. Epistemic justice fosters the contestation of ideas in the public sphere (this could be a university or on a micro level, a university classroom) and this in turn requires fostering pedagogical conditions of epistemic justice. Epistemic injustice not only blocks the flow of knowledge but also the flow of evidence, doubts, critical ideas and other epistemic inputs. Epistemic injustice may preclude some people from speaking for themselves or formulating their own knowledge claims. Our capability for epistemic contribution, Fricker explains, is

\footnotetext{
${ }^{57}$ Fricker, M. Epistemic Injustice. Power and the Ethics of Knowing. (2007). Oxford; Oxford University Press
} 
developed through all kinds of social (pedagogical) encounters which involve sharing information and forms of social understanding, and in which we are both givers and receivers in the project of making meaning; it requires (relational) "epistemic reciprocity", such that we are all recognized as knowers across higher education and professional setting ${ }^{58}$. By way of contrast, epistemic injustice in university classrooms and clinical practice settings might include silencing, having less status in the communicative practices, being marginalized, being discriminated against, and so on ${ }^{59}$. Thus, epistemic justice and injustice processes are central to our lives in education.

Higher education is demonstrably a space where epistemic justice matters; it is after all where being a knower and being able to act as a knower to gain epistemic access and develop epistemic agency is rather important. In the context of higher education testimonial injustice can include, as noted earlier in citing Hookway, the asking of questions which are ignored because of prejudice against the speaker ${ }^{60}$. As Fricker explains, it extends to cases where a speaker (for example, a student) "expresses a personal opinion to a hearer, or airs a value judgment or tries out a new idea or

\footnotetext{
${ }^{58}$ Fricker, M. Epistemic Injustice. Power and the Ethics of Knowing. (2007). Oxford; Oxford University Press

${ }^{59}$ Kidd. I., Medina, J, and Pohlhaus, G. Jr. 'Introduction' (2017).; in Kidd. I., Medina, J, and Pohlhaus, G. Jr (Eds.). The Routledge Handbook of Epistemic Injustice. (2017). London \& New York: Routledge.

${ }^{60}$ Hookway, C. 'Some Varieties of Epistemic Injustice: Reflections on Fricker'. (2010)., Episteme: A Journal of Social Epistemology, 7 (2):151-163
} 
hypothesis on a given audience" 61 . The asking or contributing of questions is then, says Fricker, potentially vulnerable to a prejudicial credibility deficit. This may be exacerbated where the student's communicative performance - either or both their expressive style or confidence in English - is also in play ${ }^{62}$. The point is that the credibility judgment includes, says Fricker, both what is said and the speaker. Such pedagogic "failure first" 63 exposes dependence on social uptake so that, while some are enabled by just conditions to make their epistemic contributions, others find their capability 'thins' or disappears altogether in some contexts. In the pedagogical context epistemic injustice, and especially prejudice-based testimonial injustice, thus unfairly increases academic and communicative labour for those whose epistemic contributions are filtered when students come together pedagogically, such that this can be identified also as an agency injustice.

Thus, Fricker suggests that societies (including education institutions) train our sensibilities in ways which are flawed, given the prejudices that exist ${ }^{64}$. The virtue

\footnotetext{
${ }^{61}$ Fricker, M. 'Epistemic Injustice and the Preservation of Ignorance.' (2016). In: Peels, R. and Blaauw, M., (eds) The Epistemic Dimensions of Ignorance. (2016). Cambridge: Cambridge University Press, 144-159., pp.148

${ }^{62}$ Medina, J. 'Varieties of Hermeneutical Injustice 1.' (2017). in Kidd. I., Medina, J, and Pohlhaus, G. Jr (Eds.). The Routledge Handbook of Epistemic Injustice. (2017). London \& New York: Routledge.

${ }^{63}$ Fricker, M. 'Epistemic Contribution as a Central Human Capability' (2015). In G. Hull (Ed.) The Equal Society. (2015). Cape Town: UCT Press, 73-90

${ }^{64}$ Fricker, M. Epistemic Injustice. Power and the Ethics of Knowing. (2007). Oxford; Oxford University Press
} 
required she proposes, is "reflexive critical awareness" 65 in order to identify how far our suspected prejudices have influenced our judgment. We can learn to become virtuous hearers through ethical reflection where we are put in a position to know better and reflexive critical awareness is placed pedagogically within our reach; it must constitute part of the conditions of educational possibility. Privileged hearers needs to learn how consciously to revise their epistemic judgements upwards.

Pedagogical conditions would need to enable processes for the epistemic capability to take the shape of supportive opportunities for developing the virtue: co-operation, taking pleasure in the achievements [learning] of others, judging others to have dignity, compassion, respect and recognition, and so on, would characterize pedagogy and ethical learning to advance the capability. Bohman highlights students being placed in a position to learn the skill of initiating dialogue or making a proposal about an issue ${ }^{66}$. Secondly, he notes learning the ability to engage productively in argument and counter-argument (in ways that are respectful of and value all identities). Thirdly, students need skills in finding ways to harmonize all proposals on the table, that is, in coming to agreement. Finally, students need to learn how to persuade in debate but not to manipulate. Pedagogical conditions would need to provide the freedom processes for the epistemic capability to take the shape of actual opportunities: co-operation, taking pleasure in the

\footnotetext{
${ }^{65} \mathrm{Ibid},(2007) .$, pp.91

${ }^{66}$ Bohman, J. Public Deliberation: Pluralism, Complexity and Democracy. (1997) Cambridge, MA: MIT Press
} 
achievements [learning] of others, judging others to have dignity, compassion, respect and recognition, and so on, would characterize pedagogy and ethical learning to advance the capability. I think therefore that the form of education and training that will foster public-good professional values is a form of praxis pedagogy which is transformative, critical, and attentive both to knowledge and to responsible action in society ${ }^{67}$. Praxis is understood here to involve both the integration of academic knowledge (acquired at university) and practical knowledge about how one lives as a professional, as a citizen and as a human being.

According to Fricker, if supportive conditions are in place, no one with relevant epistemic materials to offer would be prevented from doing so for "epistemically irrelevant" reasons, for example, because they were poor, or a migrant, or different in some way ${ }^{68}$. All students then ought to be able "to contribute to the common cognitive store [knowledge and understanding] in this pedagogical way, and thereby enjoy the mutual regard and trust that go with epistemic reciprocity" ${ }^{69}$. Students would need themselves to develop, and be supported pedagogically in developing, virtues of being confident, inquiring, curious, probing and engaged. Pedagogical processes would need to be

\footnotetext{
${ }^{67}$ See Walker, M., \& McLean, M. Professional education, capabilities and contributions to the public good. (2013) London: Routledge.

${ }^{68}$ Fricker, M. 'Epistemic Contribution as a Central Human Capability'. (2015). In G. Hull (Ed.) The Equal Society. (2015). Cape Town: UCT Press, 73-90, 2015, pp.12

${ }^{69} \mathrm{Ibid},(2015) .$, pp.22
} 
enabling of the learning of all students, creating spaces both to acquire and contribute to knowledge in the classroom, and searching for meaning and making judgements about trustworthy knowledge.

We need, I think, a measure of education-facing optimism that there are epistemic spaces of possibility if we cultivate the appropriate virtues. Plurality (for example diversity among students and among who gets to be a lawyer) - potentially if not guaranteed offers possibility for epistemic dissidence by means of a diversity of interpretative resources and practices and the inclusion and consideration of as many positional objectivities as possible. Plurality is of special importance to universities where scholars, teachers and students require inclusive epistemic freedoms in order to "to inquire, to question and probe established views and new visions without fear of retribution or silencing" ${ }^{\prime \prime 7}$. Free and open exchanges in university classrooms and public spaces are 'a necessary condition for the pursuit of knowledge' and for developing our epistemic capabilities.

If we agree with Stefan Collini that, whatever else they might do, universities are dedicated to the pursuit of understanding through open-ended inquiry, then even at this minimalist level, we must foster the epistemic contribution capability for all students as

${ }^{70}$ Ben-Porath, S. Free Speech on Campus. (2017). Philadelphia: University of Pennsylvania Press 
future professionals ${ }^{71}$.

Nonetheless, Fricker arguably, and we ourselves, may underestimate the social difficulty in developing such virtues. Students from advantaged backgrounds may fail to see or understand suffering and deprivation, or to know it exists but be indifferent if there is no impact on their own lives and careers (especially making money). Simply thinking about the problem or having access to rational knowledge (such as through digital stories) is important, but may not always be enough to the moral shifts required. Experiential learning may then be especially powerful and have the potential to change the way we see or think about the world in ways that abstract debates including rational deliberation about justice for all may fail to $\mathrm{do}^{72}$.

We might place, say, before, say a group of middle class English students, statistics and stories which demonstrate income and class-based inequalities in an area in a community in which legal clinic outreach operates that they can deliberate, coolly and rationally and reach articulate agreement that the situation is morally wrong - but yet find them unchanged at the level of moral conduct. There are numerous instances of people with apparently liberal views who are "viscerally prejudiced"73 in practice, even though at an

\footnotetext{
${ }^{71}$ Collini, S. What Are Universities For? (2012). London: Penguin Books

72 Arpaly, N. Unprincipled Virtue: An Inquiry Into Moral Agency. (2003). Oxford: Oxford University Press ${ }^{73}$ Arpaly, N. Unprincipled Virtue: An Inquiry Into Moral Agency. *2003). Oxford: Oxford University Press, pp.10
} 
abstract level they would acknowledge that such prejudice (of race, class, gender, religion, nation, and so on) is morally wrong. Equally, we may find a student suddenly confronted with interactions with a real person, who embodies his or her fears of the other, responding in a morally good way. An example from history is provided by David Brion Davis by Drew Gilpin Faust of his third book in a trilogy on the history of slavery in the U.S. Davis's overarching interest is in how ideas are refracted through real human problems in the everyday world ${ }^{74}$. For example, his concern with how a human being can come to deny and obliterate the humanity of others. For Davis slavery came to be a vehicle for examining how humans shape and are shaped by moral dilemmas and how their ideas come to influence their society and world. His own epiphany occurred while serving in the U.S. army towards the end of World War 2. On a troopship headed for Germany and ordered to descend into the hold and enforce the prohibition against gambling he discovered hundreds of black soldiers whom he had not even known were on board- segregated in slave like conditions. Gilpin Faust suggests that these army experiences introduced him to the realities of racial prejudice and cruelty that he had never imagined still existed ${ }^{75}$. The point is we can act morally without deliberation ${ }^{76}$, so we cannot assume that rational deliberation will enable a transparent awareness of

\footnotetext{
${ }^{74}$ See Faust, D.G. 'The Scholar Who Shaped History'. (2014). New York Review of Books, 20 March 2014. Available at https://www.nybooks.com/articles/2014/03/20/scholar-who-shaped-history/ 75 Ibid, (2014).

${ }^{76}$ Arpaly, N. Unprincipled Virtue: An Inquiry Into Moral Agency. (2003). Oxford: Oxford University Press
} 
actions and reasons for action and necessarily lead to moral action, although of course it may, especially if combined with particular kinds of experiences which trigger moral awareness. Higher education should probably offer both abstract deliberation (a core function of higher learning), but combine this with the potential power of experiential learning. It may then be that Nussbaum's "narrative imagination"77- being able to understand the world from the perspective of someone different from oneself - is a crucial aspect of the justice-facing epistemic contribution capability

\section{‘Combined capabilities’}

Because the person is understood as a social being, shaped by and involved in structures, processes and relationships in her society, 'combined capabilities' are of special concern ${ }^{78}$. These consist in "internal capabilities" that is, "developed states of the person him/herself that are, so far as the person herself is concerned, sufficient conditions for the exercise of the requisite functions"79. To achieve a functioning requires both the internal capability (ability, aspirations, and so forth) and supportive uptake conditions for the actual exercise of a functioning (actually doing it and not only being able to do it) - these become combined capabilities. Claassen comments that "only the latter are full capabilities,

\footnotetext{
77 Nussbaum, M. Cultivating Humanity: A Classical Defense of reform in Liberal Education. (1997). Cambridge, MA: Harvard University Press, pp.390

${ }^{78}$ Ibid, (2000).

79 Ibid, (2000)., pp.84
} 
providing us with effective freedom, with the real opportunities to do or be something" 80 . Of course, social conditions also shape the development of internal capabilities, for example, in the case of aspirations having access to teachers or family or significant others to foster the capability. Without suitable opportunities, an internal capability may not develop well, or it may develop but not be achieved.

Figure 2: Combined capabilities

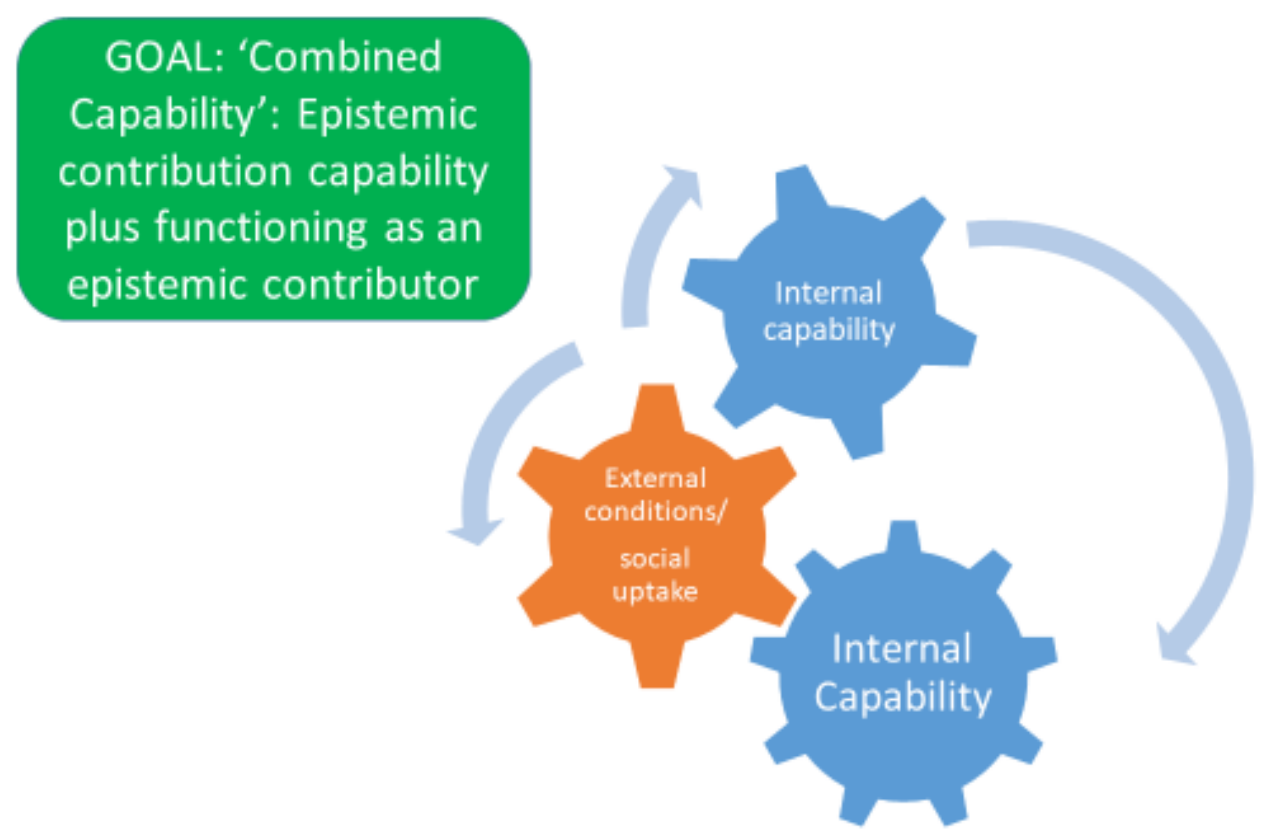

It is then combined capabilities that matter for assessments of justice and for students and others having the freedoms to shape their own lives. Thus, the epistemic contribution capability would need to be one such combined capability and hence to be achievable as

${ }^{80}$ Claassen, R. Capabilities in a Just Society. (2018). Cambridge: Cambridge University Press, pp.54 
a functioning for legal students, legal practitioners and wider publics. Indeed, all the capabilities on mine and Monica's list would be combined capabilities so that both the capability and its achievement would be important in assessments of epistemic justice in professional education processes and outcomes ${ }^{81}$.

\section{CONCLUDING THOUGHTS}

By doing particular kinds of educational things universities educate particular kinds of professionals. These particular kinds of things ought to be to educate public-good professionals, with the capabilities to act responsibly towards others. In the arena of professional, including clinical legal education, this ought to translate into human development in which students learn not only knowledge and skills but the difference between simply having a professional skill on one hand, and on the other having the commitment to use that skill to the benefit of others and to continue questioning and extending expert knowledge and its applications.

In our project, Monica McLean and I were concerned with the education of professionals who are, ethical professional agents who act to remove injustice, who are able to see more

\footnotetext{
81 also see Walker. M. Higher Education Pedagogies. (2006). Maidenhead: Open University Press \& SRHE for the capabilities vs functionings argument for higher education
} 
humanely; our personal choices matter for social justice. We then all need to accept responsibility for which epistemic practices enable and which constrain. Agents - that is ourselves and others- produce and reproduce cultures and the unequal power relations which benefit the already advantaged. The assertion of responsibility for (epistemic) justice does not allow any group, which complies with, or assists in constructing structures of domination, or fails to work with others to ameliorate conditions, to get a 'free pass', and this seems important everywhere. Thus Iris Marion Young advances a "social connection" model of responsibility, which "finds that all those who contribute by their actions to structural processes with some unjust outcomes share responsibility for the injustice" 82 - we ought to be held responsible and obligated to work towards removing this as integral to our professional ethics if we continue to be part of our society. Epistemic ignorance (or blindness) is then not excusable if the tools exist to enable us to see differently and see better and a person or group nonetheless refuses to embrace the conceptual resources that would allow full understanding of domination and epistemic inequalities. Moreover, in this way effectively to reduce or destroy the epistemic resources people need to make sense of their own lives and to communicate these lives to others is to deny participation in a shared way of life.

82 Young, I. M. Responsibility for Justice. (2011). Oxford: Oxford University Press 
I hope I have shown that epistemic justice matters for its effects not only on the epistemic but for the wider impact exclusions can have on individual lives and structures, and hence that the epistemic contribution capability merits a place on any list of professional capabilities. It may require some rethinking of the eight capabilities in Walker and McLean $(2013)^{83}$. My argument has been that epistemic freedoms matter for our flourishing lives as citizens, as educators, as professionals. Thus, for equality all students (and their future clients) ought to have access to the capability and to have such contributions taken up socially - neither rejected nor under-rated.

Of course, there are other points of view. For example, a study by the Carnegie Foundation of Law schools in the US and Canada found that students there were discouraged from relating legal cases to the complexity of real-life cases, or to think through the social consequences or ethical aspects of conclusions ${ }^{84}$. The report concluded that, "in their all-consuming first year, students are told to set aside their desire for justice. They are warned not to let their moral concerns or compassion for the people in the cases they discuss cloud their legal analyses. This warning does help students escape the grip of misconceptions about how the law works as they hone their analytic skills"85. Yet, as

\footnotetext{
83 Walker, M., \& McLean, M. Professional education, capabilities and contributions to the public good. (2013). London: Routledge.

${ }^{84}$ Sullivan, W., Colby, A., Wegner, J.W., Bond, L. and Sulman, L.S. 'Educating Lawyers'. (2007). Available at http://archive.carnegiefoundation.org/pdfs/elibrary/elibrary_pdf_632.pdf

85 Ibid, (2007)., pp.6
} 
Sullivan warns, "when the misconceptions are not addressed directly, students have no way of learning when and how their moral concerns may be relevant to their work as lawyers and when these concerns could throw them off track" ${ }^{\prime \prime 6}$.

Finally, then, my basic position is that a critical theory - in this case of an epistemic publicgood professional capability - is premised on the idea that there is no better way of knowing the world than by anticipating a better world ${ }^{87}$. Gramsci poses the challenge in this way: "How can the present be welded to the future, so that while satisfying the urgent necessities we may work effectively to create and 'anticipate' the other" 88 . For this we need intellectual instruments, imagination and agency to struggle towards that world against the waste of social experiences and distorted and distorting power relations, including the epistemic ${ }^{89}$. Of course, a good critical theory is also profoundly practical and it is the practical challenges of professional capabilities that can be answered only by what legal educators and their allies will do, now and in the future and under what conditions of possibility. In such practical efforts we are reminded by Nelson Mandela (himself a trained lawyer before his incarceration) in what might be considered capabilities language, that, "to be free [is] to live in a way that respects and enhances the

\footnotetext{
${ }^{86} \mathrm{Ibid},(2007)$.

${ }^{87}$ De Sousa Santos, B. Epistemologies of the South: Justice against Epistemicide. (2015). London and New York: Routledge.

${ }^{88}$ Gramsci, A. Selections From Political Writings (1910-1920). (1977). London: Lawrence Wishart., pp.201

${ }^{89}$ De Sousa Santos, B. Epistemologies of the South: Justice against Epistemicide. (2015). London and New York: Routledge.
} 
freedoms of others" ${ }^{\prime \prime 0}$.

\section{ACKNOWLEDGEMENTS}

A version of this paper was first presented as a keynote address to the annual INCLE/ENCLE conference in Bratislava, 3-5 July 2019. My thanks to the organisers for inviting me and to conference participants for helpful ideas. The current higher education research work on which the paper draws is funded by NRF grant 86540 for my research chair. Previous work on professional capabilities with Monica McLean was funded by ESRC Grant RES- 167-25-0302. My especial thanks to Monica Mclean for so many stimulating conversations and generative collaborations over the years.

${ }^{90}$ Mandela, N. Long Walk to Freedom: The Autobiography of Nelson Mandela, (1995). London: Abacus., pp.290 